\title{
Laparoscopic management of an 11-week rudimentary uterine horn pregnancy using extracorporeal Roeder knot to secure the dilated vascular pedicle
}

\author{
Vasileios Minas • Elizabeth Shaw • Thomas Aust
}

Received: 3 December 2013 / Accepted: 20 January 2014 / Published online: 24 April 2014

(C) Springer-Verlag Berlin Heidelberg 2014

\begin{abstract}
Pregnancy in a uterine rudimentary horn carries a high risk of uterine rupture with severe and potentially lethal intra-abdominal haemorrhage. There is now growing evidence that this condition can be safely managed by minimally invasive surgery. We report a case of an unruptured 11-week rudimentary horn pregnancy that was diagnosed and treated laparoscopically. We have performed a literature review using PubMed, Embase and Cochrane Database of Systematic Reviews to identify relevant cases and draw conclusions with regards to their management. We have collated 20 published cases of rudimentary horn pregnancies that were managed by laparoscopy. The surgical technique appears consistent among these cases with few variations. In advanced gestations, feticide may need to be performed. Morcellation has been shown to be possible without compromising patient safety from trophoblast spill. The possibility of uncommon presentations such as duplicated or absent ureter should be taken into account. Extracorporeal Roeder knot can be used safely to secure unusually dilated vascular pedicles. Overall, laparoscopy appears to be as safe as and potentially superior to laparotomy for the management of rudimentary horn pregnancies.
\end{abstract}

Keywords Rudimentary horn pregnancy $\cdot$ Uterine malformations $\cdot$ Laparoscopy $\cdot$ Extracorporeal knot

V. Minas $(\triangle) \cdot$ E. Shaw $\cdot$ T. Aust

Minimal Access Centre, Department of Obstetrics and Gynaecology,

Wirral University Teaching Hospital, Arrowe Park Rd, Wirral,

Merseyside CH49 5PE, UK

e-mail: billminas@gmail.com

\section{Introduction}

A rudimentary uterine horn results from incomplete embryological development of one of the two Müllerian duct systems. More than 500 cases of rudimentary horn pregnancies (RHPs) have been reported to date [1]. This is a rare form of ectopic pregnancy with reported incidence that ranges from 1:76,000 to $1: 140,000$ pregnancies [1]. The natural course of such pregnancies is rupture either in the first or mid-second trimester. Only $10 \%$ reaches a term with a fetal survival rate ranging from 0 to $13 \%$ and maternal mortality rates up to $0.5 \%[1,2]$. Accurate diagnosis and appropriate management are therefore crucial to prevent risk to the mother from the current and future pregnancies.

\section{Case report}

A 29-year-old woman, with one previous normal delivery at term, presented to our unit for her routine dating ultrasound scan (USS). She was amenorrhoeic for 12 weeks and had a positive urine pregnancy test. Trans-abdominal and transvaginal USS revealed an $11^{+6}$-week live extra-uterine pregnancy (Fig. 1). We suspected either a RHP or an abdominal pregnancy, and plans were made for a laparoscopy to accurately diagnose the location of the pregnancy and potentially remove it at the same time. At laparoscopy, a left RHP was diagnosed (Fig. 2). A small band of fibromuscular tissue approximately $3-\mathrm{cm}$ long and $0.5-\mathrm{cm}$ thick was seen connecting the rudimentary horn with the uterus. There was no hemoperitoneum. A decision to proceed with horn excision was made. The rudimentary horn was excised intact using a combination of LigaSure ${ }^{\mathrm{TM}}$ (Valleylab, Colorado, USA) and extracorporeal knot tying (Roeder knots) (Biosyn 1 suture) [3] (Fig. 2). The course of the left ureter was first identified. A left salpingectomy was performed to prevent future ipsilateral 
Fig. 1 Ultrasonographic findings of the presented case. a

Transabdominal ultrasound showing an extra-uterine live pregnancy of $11^{+6}$-week gestational age. b Transvaginal ultrasound scan confirming the above findings. $u$ uterus, $f$ fetus
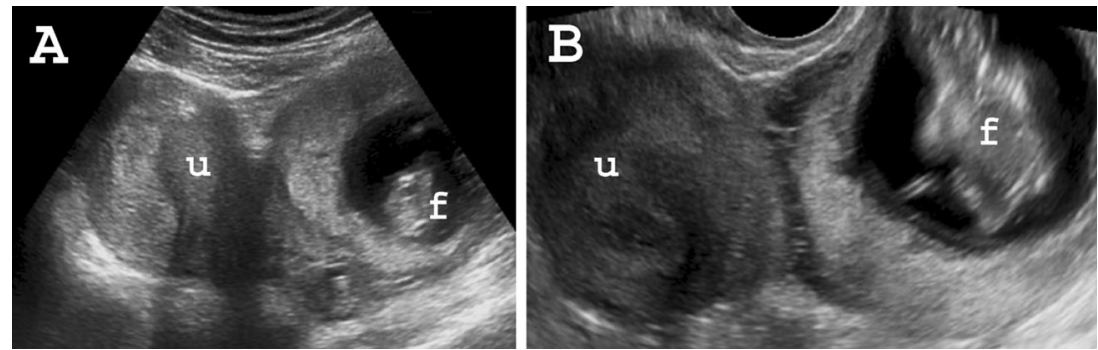

tubal ectopic pregnancies. The left round ligament was then transected, and the anterior leaf of the broad ligament and the bladder were dissected off the uterine horn. A fenestration was made to the posterior leaf of the left broad ligament and used to pass a suture and tie an extracorporeal Roeder knot around the large dilated vessels of the ovarian ligament pedicle. The pedicle was secured with two ties, and the rudimentary horn was thus separated from the left ovary. The remaining fibromuscular connection between the rudimentary horn and the unicornuate uterus was secured with a Roeder knot and
Fig. 2 Intra-operative findings and procedures: a, b A left RHP was diagnosed at laparoscopy. The structures associated with the rudimentary horn (left ovary, fallopian tube and round ligament) were identified. c A fibromuscular band of tissue connecting the rudimentary horn with the unicornuate uterus was seen (the probe is resting on the tissue). d A left salpingectomy is done. e The round ligament (black arrow) is transected, and the anterior leaf of the broad ligament and bladder flap are dissected. A fenestration was made in the posterior leaf of the broad ligament. f The ovarian ligament is seen containing large dilated vessels of approximately 15$20 \mathrm{~mm}$ in diameter. The pedicle is tied with extracorporeal Roeder knot and transected. $\mathbf{g}$, h The connection between the rudimentary horn and the unicornuate uterus is tied with an extracorporeal knot, and the horn is finally separated (the knot is secured with a knot pusher). $r$ round ligament, $f$ fallopian tube, $o$ ovary, $r$ rudimentary horn, $u$ unicornuate uterus
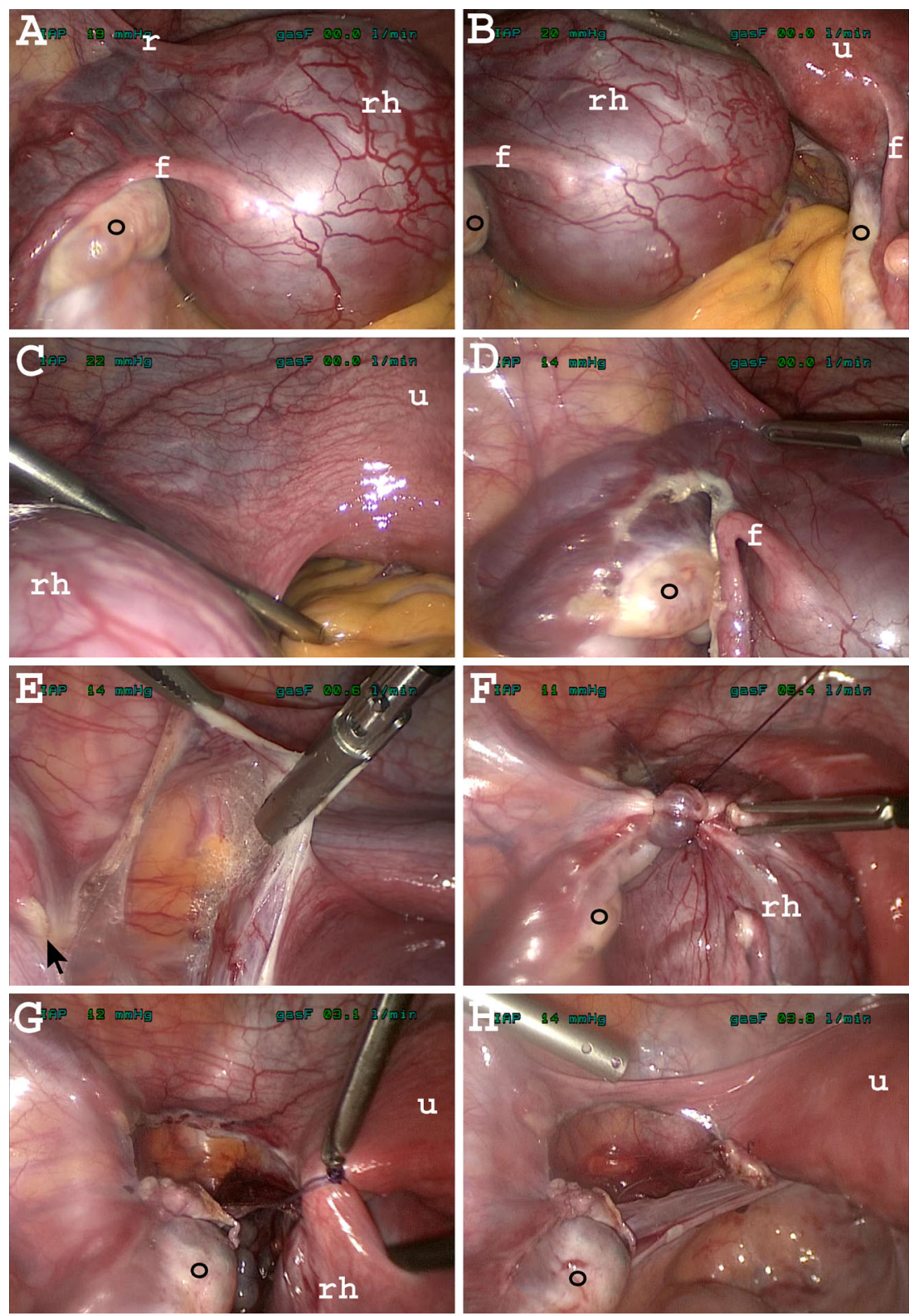
transected with LigaSure ${ }^{\mathrm{TM}}$ to complete the horn excision. The suprapubic laparoscopic incision was extended to $3 \mathrm{~cm}$, and the specimen was extracted in a nylon bag. At the conclusion of the procedure, a hysteroscopy was performed which revealed a normal vagina, single cervix with a single cervical canal leading to a right-sided non-gravid unicornuate uterus with no communication with the rudimentary horn. The procedure took $57 \mathrm{~min}$. Estimated blood loss was less than $50 \mathrm{ml}$, and the patient went home on the first post-operative day.

\section{Discussion}

Women with a unicornuate uterus associated with a rudimentary horn may experience various pregnancy and nonpregnancy-related complications. These include endometriosis, hematometra, infertility, recurrent miscarriages, uterine rupture and abnormally adherent placenta [4]. Renal tract anomalies also occur in $38 \%$ of such patients [5]. Pregnancies occurring in non-communicating rudimentary horns are thought to result from transperitoneal migration of either spermatozoa or the fertilized ovum which reaches the peritoneal cavity via the contralateral tube [6].

The diagnosis of RHP can be difficult. Jurkovic et al. reported an USS sensitivity for the diagnosis of RHP of $26 \%$ [7]. Subsequently, other authors have attempted, through short series of cases, to develop specific USS criteria to facilitate preoperative diagnosis [8]. A recent literature review showed that only $5 \%$ of the reported RHPs were diagnosed pre-operatively [9], whereas our search of laparoscopically managed RHP revealed that 9/20 (45\%) were confidently diagnosed pre-operatively. Jihong et al. reported that their case was misdiagnosed by USS as missed miscarriage at 5, 7 and 8 weeks of gestational age. An endometrial curettage was eventually performed that yielded no pregnancy tissue. They finally diagnosed a RHP at 12 weeks by laparoscopy, following a repeat USS which suggested a tubal ectopic pregnancy [10]. In the present case, our differential diagnosis preoperatively included both abdominal pregnancy and RHP, and we conclusively diagnosed the RHP at laparoscopy. Missed diagnoses at laparoscopy have also been reported. A case of a 16-week ruptured RHP was initially thought to be an intra-uterine pregnancy developing in a bicornuate uterus at laparoscopy performed at 7 weeks for abdominal pain [11]. Magnetic resonance imaging (MRI) can help differentiate between a RHP and a pregnancy in a bicornuate uterus which can be potentially viable [9].

Due to the thin and poorly developed myometrium, most RHPs rupture between 10 and 20 weeks of gestational age [2]. Therefore, once diagnosed, management of such pregnancies includes excision of the rudimentary horn together with the ipsilateral fallopian tube to prevent future ectopic pregnancies [15]. Similarly, planned removal of rudimentary horns is advised when those are diagnosed pre-pregnancy in women who desire future pregnancies [12].

The majority of reported RHPs ( $>97 \%$ ) have been managed by laparotomy. That is usually due to either lack of advanced laparoscopic skills by the involved surgeons or because the clinicians encountered a haemodynamically unstable patient with a ruptured horn. We have collated 20 reported RHPs which have been managed laparoscopically in Table 1 (including the current case). A number of different instruments have been used to achieve excision of the rudimentary horn, including bipolar forceps and scissors, LigaSure $^{\mathrm{TM}}$, Harmonic ${ }^{\circledR}$ scalpels, Endoloops ${ }^{\circledR}$ and stapling devices. The surgical technique is consistent among most of these reports and includes the steps described in our case. Few variations have been reported. Yan injected vasopressin into the fibromuscular band to reduce its vascularity prior to transection [13], whereas other authors used Endoloops ${ }^{\circledR}$ to secure their vascular pedicles [14].

We used extracorporeal Roeder knots to secure our vascular pedicles. This type of knot has been shown to be one of the strongest laparoscopic slip knots [15], and we have found it consistently safe when performing laparoscopic hysterectomies. The uterine blood supply in pregnancy rises gradually until the end of week 9 and thereafter rapidly with concomitant dilatation of the uterine vasculature [16]. In particular, in our case, the ovarian ligament was seen containing large dilated vessels with the whole pedicle measuring $20-25 \mathrm{~mm}$ in diameter (Fig. 2f). Therefore, suture ligation was preferred over coagulation.

When planning such a procedure, there are a few important points to be kept in mind. Pre-operative intravenous urography and/or intra-operative ureterolysis may be necessary particularly in cases associated with urinary tract malformations (such as ureteric duplication and absent kidney/ureter) or significant endometriosis [17]. Nevertheless, very few of the authors shown in Table 1 endorsed the above two measures. Still, the ureter must be confidently identified before the excision of the rudimentary horn [18]. An ipsilateral salpingectomy should be performed in all cases to prevent future tubal ectopic pregnancies [18]. The type of connection between the unicornuate uterus and the rudimentary horn must be defined [19]. Thin connections are relatively easy to deal with and can be transected either by coagulation or by suture ligation. In our case, we coagulated the uterine artery with bipolar diathermy and secured the connecting tissue pedicle with an extracorporeal Roeder knot. When the rudimentary horn is firmly attached to the unicornuate uterus, haemostasis may be more difficult. In these cases, the myometrium of the remaining uterus should be repaired by suturing following horn excision to reduce the risk of rupture in future pregnancies [20]. 
Table 1 Twenty cases of rudimentary horn pregnancies managed laparoscopically

\begin{tabular}{|c|c|c|c|c|c|c|c|c|c|}
\hline author & $\begin{array}{l}\text { Patient } \\
\text { age } \\
\text { (years) }\end{array}$ & $\begin{array}{l}\text { Gestational } \\
\text { age (weeks) }\end{array}$ & Parity & Imaging tools & $\begin{array}{l}\text { Pre-operative } \\
\text { diagnosis }\end{array}$ & $\begin{array}{l}\text { Pre-operative } \\
\text { rupture }\end{array}$ & $\begin{array}{l}\text { Medical } \\
\text { treatment }\end{array}$ & $\begin{array}{l}\text { Horn excision } \\
\text { technique }\end{array}$ & $\begin{array}{l}\text { Tissue/fetus } \\
\text { extraction technique }\end{array}$ \\
\hline $\begin{array}{l}\text { Dulemba et al } \\
(1996)(24)\end{array}$ & 26 & 13 & & USS & $\begin{array}{l}\text { Right isthmic tubal } \\
\text { pregnancy }\end{array}$ & no & no & $\begin{array}{l}\text { Bipolar } \\
\text { forceps }\end{array}$ & \\
\hline $\begin{array}{l}\text { Dicker et al } \\
(1998)(17)\end{array}$ & 31 & 8 & P0 & USS & $\begin{array}{l}\text { Right cornual } \\
\text { pregnancy }\end{array}$ & no & no & $\begin{array}{l}\text { Bipolar } \\
\text { forceps }\end{array}$ & $\begin{array}{l}15 \mathrm{~mm} \text { suprapubic } \\
\text { incision }\end{array}$ \\
\hline $\begin{array}{l}\text { Yahata et al } \\
(1998)(25)\end{array}$ & 22 & 7 & P0 & USS & $\begin{array}{l}\mathrm{RHP} / \text { isthmic/cornual } \\
\text { pregnancy }\end{array}$ & no & no & $\begin{array}{l}\text { Stapling } \\
\text { device }\end{array}$ & \\
\hline $\begin{array}{l}\text { Yoo et al } \\
(1999)(26)\end{array}$ & 23 & 8 & P0 & USS & RHP/tubal pregnancy & no & no & $\begin{array}{l}\text { Bipolar } \\
\text { forceps }\end{array}$ & $\begin{array}{l}\text { Endobag through } \\
11 \mathrm{~mm} \text { incision }\end{array}$ \\
\hline $\begin{array}{l}\text { Adolph and } \\
\text { Gilliland } \\
(2002)(27)\end{array}$ & 25 & 6 & P0 & USS & Right RHP & no & no & $\begin{array}{l}\text { Stapling } \\
\text { device }\end{array}$ & $\begin{array}{l}\text { Bag through } 12 \mathrm{~mm} \\
\text { incision }\end{array}$ \\
\hline $\begin{array}{l}\text { Edelman } \\
(2003)(22)\end{array}$ & 24 & 6 & P0 & USS; MRI & RHP & no & MTX & & Morcellation \\
\hline $\begin{array}{l}\text { Chakravarti } \\
\text { and Chin } \\
(2003)(28)\end{array}$ & 23 & 9 & & USS & $\begin{array}{l}\text { Left adnexal } \\
\text { pregnancy }\end{array}$ & no & no & & \\
\hline $\begin{array}{l}\text { Cutner et al } \\
(2004)(23)\end{array}$ & 32 & 12 & P0 & 3D USS & Right RHP & no & $\begin{array}{l}\text { KCL;MTX; } \\
\text { GnRHa }\end{array}$ & $\begin{array}{l}\text { Harmonic } \\
\text { scalpel; } \\
\text { bipolar forceps }\end{array}$ & Morcellation \\
\hline $\begin{array}{l}\text { Cutner et al } \\
(2004)(23)\end{array}$ & 32 & & P0 & USS; MRI & Right RHP & no & $\begin{array}{l}\text { KCL;MTX; } \\
\text { GnRHa }\end{array}$ & $\begin{array}{l}\text { Harmonic } \\
\text { scalpel; } \\
\text { bipolar forceps } \\
\end{array}$ & Morcellation \\
\hline $\begin{array}{l}\text { Sonmezer et } \\
\text { al }(2006)(20)\end{array}$ & 28 & 6 & $\mathrm{P} 0$ & USS & Right RHP & no & no & $\begin{array}{l}\text { Bipolar } \\
\text { forceps }\end{array}$ & $\begin{array}{l}\text { Endobag through } \\
10 \mathrm{~mm} \text { incision }\end{array}$ \\
\hline $\begin{array}{l}\text { Park and } \\
\text { Dominguez } \\
(2007)(5)\end{array}$ & 36 & 8 & P1 & USS; MRI & Right RHP & no & KCL;MTX & LigaSure & $\begin{array}{l}\text { Endobag through } \\
10 \mathrm{~mm} \text { incision }\end{array}$ \\
\hline $\begin{array}{l}\text { Henriet et al } \\
(2008)(12)\end{array}$ & 28 & 7 & P0 & USS & Left RHP & no & no & $\begin{array}{l}\text { Bipolar } \\
\text { forceps }\end{array}$ & \\
\hline $\begin{array}{l}\text { Kadan and } \\
\text { Romano } \\
(2008)(18)\end{array}$ & 37 & 11 & & USS & Left RHP & no & no & $\begin{array}{l}\text { Bipolar } \\
\text { forceps }\end{array}$ & $\begin{array}{l}\text { Horn placed in } \\
\text { Endobag, incised and } \\
\text { contents suctioned; } \\
\text { right incision slightly } \\
\text { enlarged for } \\
\text { extraction }\end{array}$ \\
\hline $\begin{array}{l}\text { Contreras et } \\
\text { al }(2008)(21)\end{array}$ & 27 & 19 & P1 & USS; CT & $\begin{array}{l}\text { Abdominal/cornual } \\
\text { pregnancy }\end{array}$ & no & no & $\begin{array}{l}\text { Harmonic; } \\
\text { Stapling } \\
\text { device }\end{array}$ & $\begin{array}{l}\text { Laparoscopic } \\
\text { amnioreduction; } \\
\text { Hand-assist port } \\
\text { through } 4 \mathrm{~cm} \\
\text { suprapubic incision }\end{array}$ \\
\hline $\begin{array}{l}\text { Jihong et al } \\
(2009)(10)\end{array}$ & 27 & 5 & P1 & USS & $\begin{array}{l}\text { USS at } 5,7 \text { and } 8 \\
\text { weeks } \rightarrow \text { missed } \\
\text { miscarriage; USS at } \\
12 \text { weeks } \rightarrow \text { right } \\
\text { adnexal pregnancy }\end{array}$ & no & no & $\begin{array}{l}\text { Bipolar } \\
\text { forceps; } \\
\text { endoloop }\end{array}$ & \\
\hline $\begin{array}{l}\text { Szabo et al } \\
(2009)(29)\end{array}$ & 30 & 9 & & & & & & & \\
\hline $\begin{array}{l}\text { Shahid et al } \\
(2010)(11)\end{array}$ & 33 & 16 & $\mathrm{P} 0$ & FAST USS & $\begin{array}{l}\text { Ruptured ectopic } \\
\text { pregnancy }\end{array}$ & $\begin{array}{l}\text { yes (3 lt } \\
\text { haemo- } \\
\text { peritoneum) }\end{array}$ & no & $\begin{array}{l}\text { Horn excised } \\
\text { at later } \\
\text { procedure; } \\
\text { Harmonic } \\
\text { scalpel and } \\
\text { bipolar forceps } \\
\text { used to extend } \\
\text { rupture }\end{array}$ & $\begin{array}{l}\text { Endobag through } \\
3 \mathrm{~cm} \text { suprapubic } \\
\text { incision (for fetus and } \\
\text { placenta extraction) }\end{array}$ \\
\hline $\begin{array}{l}\text { Yan (2010) } \\
(13)\end{array}$ & 33 & 5 & P1 & USS & $\begin{array}{l}\text { Right tubal } \\
\text { pregnancy }\end{array}$ & no & no & $\begin{array}{l}\text { Ultrasonic } \\
\text { scalpel; } \\
\text { bipolar forceps }\end{array}$ & Posterior colpotomy \\
\hline $\begin{array}{l}\text { Lennox et al } \\
(2013)(14)\end{array}$ & 28 & 16 & P0 & USS; MRI & Left RHP & no & $\mathrm{KCL}$ & $\begin{array}{l}\text { Ligasure; } \\
\text { endoloop }\end{array}$ & $\begin{array}{l}\text { Morcellation; } \\
\text { Endobag through } \\
2.5 \mathrm{~cm} \text { lateral incision }\end{array}$ \\
\hline \multirow[t]{2}{*}{ Present case } & 29 & 11 & P1 & USS & $\begin{array}{l}\text { RHP/abdominal } \\
\text { pregnancy }\end{array}$ & no & no & $\begin{array}{l}\text { Ligasure; } \\
\text { extra-corporeal }\end{array}$ & $\begin{array}{l}\text { Endobag through } \\
3 \mathrm{~cm} \text { suprapubic }\end{array}$ \\
\hline & & & & & & & & Roeder's knots & incision \\
\hline
\end{tabular}

The cases in grey shade represent second trimester pregnancies as opposed to the rest which are in the first trimester. Where information is lacking, the respective fields have been left blank. The case of Szabo et al. is published in Hungarian, and we were therefore unable to extract any information from the main text. RHP rudimentary horn pregnancy, $M T X$ methotrexate, $\mathrm{KCl}$ potassium chloride, FAST USS focused assessment with sonography for trauma, GnRHa gonadotrophin-releasing hormone analogue

Extraction of specimens in laparoscopy is often a challenge. In our review, the majority of authors were able to extract their specimens through a small extension of one of the laparoscopic ports (up to $3 \mathrm{~cm}$ ). Similarly, we extended the suprapubic port to $3 \mathrm{~cm}$ and extracted the uterine horn containing the intact pregnancy in a nylon bag. We were thus able 
to reassure the patient that no destructive techniques (such as morcellation) were applied to remove the fetus. When the size of the pregnancy/fetus was such that morcellation was required, some authors elected to perform feticide with intracardiac $\mathrm{KCl}$ prior to the laparoscopy [12]. Lennox et al. brought their specimen to the skin (16-week RHP) in an EndoCatch ${ }^{\mathrm{TM}} \mathrm{bag}$, then morcellated the tissues and extracted them with Beirer forceps [12]. Contreras et al. performed laparoscopic amnioreduction for a 19-week RHP and used a hand-assist port through a 4-cm suprapubic incision to extract the specimen without morcellation [21]. Kadan and Romano placed their excised horn in an Endo bag, incised it and suctioned its contents laparoscopically; they then extended their right lateral incision slightly for extraction [18]. Alternatively, a posterior colpotomy can be used [13]. Clearly, these methods allow for specimen extraction without the risk of morcellation-associated trophoblast spill and persistent trophoblastic disease, and therefore, laparotomy should not be preferred over laparoscopy on the basis of this argument.

Methotrexate has been used by some authors either with curative intent [22] or as an adjunct to surgery in an attempt to arrest the development of the pregnancy (in combination with intra-cardiac $\mathrm{KCl}$ ) and reduce the vascularity of the rudimentary horn $[5,23]$. Due to the small number of patients, it is not possible to conclude at present whether this method is of any value.

Where available, we attempted to collect data such as operating time, estimated blood loss and hospital stay for the cases shown in Table 1 (excluding the ruptured horn case where excision of the horn was performed at a later procedure). The operating times varied from 45 and 180 min with a mean operating time of $74.6 \mathrm{~min}$. The majority of cases were completed in $50 \mathrm{~min}$, and in one case only, where laparoscopic suturing was required, it took $180 \mathrm{~min}$. Estimated blood loss was reported to range from minimal up to $100 \mathrm{ml}$, with a mean blood loss of $50 \mathrm{ml}$. All patients went home either on the first or second post-operative day with a mean hospital stay of 1.25 days.

\section{Conclusion}

There exists a growing body of evidence of RHP successfully managed by laparoscopy (20 cases in total). These include second trimester pregnancies as well as a case of a ruptured horn. The surgical technique is now well described. We suggest that when encountered with large dilated vascular pedicles, securing them by extracorporeal Roeder knots is a safe alternative. In advanced gestations, patients must be counselled pre-operatively about the potential need for destructive techniques. In such cases, feticide may need to be performed. Morcellation has been shown to be possible without compromising patient safety from trophoblast spill. The possibility of uncommon presentations such as duplicated or absent ureter should be taken into account pre-operatively, and the ureter must be identified intra-operatively. When the expertise is available, laparoscopy appears to be at least as safe as and potentially superior to laparotomy for the management of RHP.

Conflict of interest statement Vasileios Minas, Elizabeth Shaw and Thomas Aust declare that they have no conflict of interest.

Statement of informed consent Informed consent was obtained from all patients for which identifying information is included in this article.

This article does not contain any studies with human or animal subjects performed by the any of the authors.

\section{References}

1. Nahum GG (2002) Rudimentary uterine horn pregnancy: the 20thcentury worldwide experience of 588 cases. J Reprod Med 47:151-163

2. Chopra S, Keepanasseril A, Rohilla M et al (2009) Obstetric morbidity and the diagnostic dilemma in pregnancy in rudimentary horn: retrospective analysis. Arch Gynecol Obstet 280:907-910

3. Sharp HT, Dorsey JH (1997) The 4-S modification of the Roeder knot: how to tie it. Obstet Gynecol 90:1004-1006

4. Fedele L, Bianchi S, Tozzi L et al (1995) Fertility in women with unicornuate uterus. Br J Obstet Gynaecol 102:1007-1009

5. Park JK, Dominguez CE (2007) Combined medical and surgical management of rudimentary uterine horn pregnancy. JSLS 11:119-122

6. Reichman D, Laufer MR, Robinson BK (2009) Pregnancy outcomes in unicornuate uteri: a review. Fertil Steril 91:1886-1894

7. Jurkovic D, Gruboeck K, Tailor A, Nicolaides KH (1997) Ultrasound screening for congenital uterine anomalies. Br J Obstet Gynaecol 104:1320-1321

8. Mavrelos D, Sawyer E, Helmy S et al (2007) Ultrasound diagnosis of ectopic pregnancy in the noncommunicating horn of a unicornuate uterus (cornual pregnancy). Ultrasound Obstet Gynecol 30:765-770

9. van Esch EM, Lashley EE, Berning B, de Kroon CD (2010) The value of hysteroscopy in the diagnostic approach to a rudimentary horn pregnancy. BMJ Case Rep. doi:10.1136/bcr.08.2010.3229

10. Jihong L, Siow A, Chern B (2009) Laparoscopic excision of rudimentary horn pregnancy in a patient with previous caesarean section. Arch Gynecol Obstet 279:403-405

11. Shahid A, Olowu O, Kandasamy G et al (2010) Laparoscopic management of a 16-week ruptured rudimentary horn pregnancy: a case and literature review. Arch Gynecol Obstet 282:121-125

12. Henriet E, Roman H, Zanati J et al (2008) Pregnant noncommunicating rudimentary uterine horn with placenta percreta. JSLS 12:101-103

13. Yan CM (2010) Laparoscopic management of three rare types of ectopic pregnancy. Hong Kong Med J 16:132-136

14. Lennox G, Pantazi S, Keunen J et al (2013) Minimally invasive surgical management of a second trimester pregnancy in a rudimentary uterine horn. J Obstet Gynaecol Can 35:468-472

15. Sharp HT, Dorsey JH, Chovan JD, Holtz PM (1996) The effect of knot geometry on the strength of laparoscopic slip knots. Obstet Gynecol 88:408-411

16. Dickey RP, Hower JF (1995) Ultrasonographic features of uterine blood flow during the first 16 weeks of pregnancy. Hum Reprod 10: 2448-2452

17. Dicker D, Nitke S, Shoenfeld A et al (1998) Laparoscopic management of rudimentary horn pregnancy. Hum Reprod 13:2643-2644 
18. Kadan Y, Romano S (2008) Rudimentary horn pregnancy diagnosed by ultrasound and treated by laparoscopy - a case report and review of the literature. J Minim Invasive Gynecol 15:527-530

19. Perrotin F, Bertrand J, Body G (1999) Laparoscopic surgery of unicornuate uterus with rudimentary uterine horn. Hum Reprod 14: 931-933

20. Sonmezer M, Taskin S, Atabekoglu C et al (2006) Laparoscopic management of rudimentary uterine horn pregnancy: case report and literature review. JSLS 10:396-399

21. Contreras KR, Rothenberg JM, Kominiarek MA, Raff GJ (2008) Hand-assisted laparoscopic management of a midtrimester rudimentary horn pregnancy with placenta increta: a case report and literature review. J Minim Invasive Gynecol 15:644-648

22. Edelman AB, Jensen JT, Lee DM et al (2003) Successful medical abortion of a pregnancy within a noncommunicating uterine horn. Am J Obstet Gynecol 189:886-887

23. Cutner A, Saridogan E, Hart R et al (2004) Laparoscopic management of pregnancies occurring in a noncommunicating accessory uterine horns. Eur J Obstet Gynecol Reprod Biol 113:106-109

24. Dulemba J, Midgett W, Freeman M (1996) Laparoscopic management of a rudimentary horn pregnancy. J Am Assoc Gynecol Laparosc 3:627-630

25. Yahata T, Kurabayashi T, Ueda H et al (1998) Laparoscopic management of a rudimentary horn pregnancy: a case report. J Reprod Med 43:223-226

26. Yoo EH, Chun SH, Woo BH (1999) Laparoscopic resection of a rudimentary horn pregnancy. Acta Obstet Gynecol Scand 78:167-168

27. Adolph AJ, Gilliland GB (2002) Fertility following laparoscopic removal of rudimentary horn with an ectopic pregnancy. J Obstet Gynaecol Can 24:575-576

28. Chakravati S, Chin K (2003) Rudimentary uterine horn: management of a diagnostic enigma. Acta Obstet Gynecol Scand $82: 1153-1154$

29. Szabó I, Börzsönyi B, Demendi C, Langmár Z (2009) Successful laparoscopic management of a noncommunicating rudimentary horn pregnancy. Orv Hetil 150:513-515 